Original Research Paper

\title{
Analisis Kesalahan Siswa dalam Menyelesaikan Soal Aritmatika Sosial Kelas VII-F SMPK St. Gerardus Mayella Kalembu Weri Tahun Pelajaran 2020/2021
}

\author{
Yasinta Anita Kette ${ }^{1}$, Samuel Rex M. Making ${ }^{2}$, Dekriati Ate $^{3}$ \\ ${ }^{1,2,3}$ Program Studi Pendidikan Matematika, Sekolah Tinggi Keguruan dan Ilmu Pendidikan Weetebula, Indonesia
}

Article history

Received: 24 July 2021

Revised: 15 October 2021

Accepted: 18 October 2021

*Corresponding Author: Yasinta Anita Kette, STKIP Weetebula, Tambolaka, Indonesia; Email: yasintaanitakette@gmail.com

\begin{abstract}
Abstrak: Penelitian ini menggunakan pendekatan kualitatif dan jenis penelitian yang dilakukan adalah deskriptif. Tujuan dilakukan penelitian ini untuk mengetahui jenis kesalahan siswa kesalahan siswa SMPK St. Gerardus Mayella Kalembu Weri dalam menyelesaikan soal aritmatika sosial. Dari 21 siswa kelas VII-A diambil 6 siswa sebagai subjek penelitian. Instrumen tes yang digunakan berbentuk uraian dengan 3 butir soal. Dari 6 subjek dapat disimpulkan bahwa dapat melakukan kesalahan berdasarkan prosedur Newman. Berasakan hasil persentase diperoleh data untuk kesalahan membaca dan memahami masalah $55 \%$, kesalahan dalam transformasi 53\%, kesalahan dalam keterampilan proses $55 \%$, dan kesalahan dalam penulisan jawaban akhir $61 \%$.

Kata kunci: Type Kesalahan Siswa, Analisis Kesalahan Newman, Aritmatika Sosial.

Abstract: This study uses a qualitative approach and the type of research carried out is descriptive. The purpose of this study was to determine the types of errors of students' errors in junior high scool st. Gerardus Mayella Kalembu Weri in solving social arithmetic problems And 21 students of class VII-A were taken 6 students as research subjects. The test instrument used was in the form of a description with 3 questions and 6 subjects it could be concluded that they could make mistakes based on the Newman procedure. Errors in reading and understanding promlems 55\%, errors in transformation 53\%, errors in processing skills $55 \%$, and errors in writing final answers $61 \%$.
\end{abstract}

Keywords: Students Error Tipe, Newman Error Analysis, Social Arithmetic

\section{Pendahuluan}

Menurut Juwita (2016:1), Seiring dengan perkembangan zaman, dunia pendidikan terus berubah dengan signifikan sehingga banyak berubah pola pikir, dari pola pikir yang awam dan kaku menjadi lebih modern. Hal tersebut sangat berpengaruh dalam kemajuan pendidikan di Indonesia. Tujuan pendidikan adalah menciptakan seseorang yang berkualitas dan berkarakter sehingga memiliki pandangan yang luas ke depan untuk mencapai suatu cita-cita yang diharapkan dan mampu beradaptasi secara cepat dan tepat di dalam berbagai lingkungan. Karena pendidikan itu sendiri memotivasi kita untuk lebih baik dalam segala aspek kehidupan.

Syahruddin (2018:1), mengatakan bahwa Pendidikan adalah kebutuhan manusia di sepanjang hidupnya. Tanpa pendidikan, manusia dapat diarahkan menjadi lebih baik dan berkualitas. Pendidikan akan terus dilakukan karena pendidikan tidak mengenal waktu dan merupakan proses yang terus berjalan sepanjang hidup manusia.

Menurut Malik (2017:1), matematika merupakan ilmu dasar yang memiliki peran yang sangat penting bagi ilmu lainnya karena digunakan secara luas dalam berbagai bidang kehidupan. Dalam rangka peningkatan sumber daya manusia, pendidikan matematika menjadi salah satu komponen yang sangat penting dan merupakan bagian yang tak terpisahkan dari pendidikan nasional. Melalui Kementerian Pendidikan Nasional, pemerintah menetapkan matematika sebagai salah satu pelajaran yang wajib diajarkan pada setiap jenjang pendidikan formal. 
Menurut Widdiharto (Malik, 2017:1), pembelajaran matematika disekolah diharapkan dapat menumbuhkan kemampuan bernalar pada diri siswa yang tercermin melalui kemampuan memecahkan masalah dengan berpikir kritis, logis, sistematis, cermat, efektif, dan efisien, serta disiplin dalam memecahkan suatu permasalahan, baik masalah dalam bidang matematika, bidang lain, maupun kehidupan sehari-hari. Salah satu pembelajaran matematika yang dapat melatih dan mengembangkan kemampuan bernalar dan pemecahan masalah siswa adalah pembelajaran soal cerita.

Menurut Rudtin (Malik, 2017:1), menyatakan bahwa pemberian soal matematika berbentuk cerita memberikan pengalaman bagi siswa untuk dapat memecahkan masalah matematika dan gambaran hubungan masalah tersebut dengan kehidupan sehari-harinya. Sedangkan menurut Hanifah (Malik, 2017:2), untuk menyelesaikan soal cerita terlebih dahulu siswa harus dapat memahami maksud dari permasalahan yang terdapat dalam soal, selanjutnya menentukan metode yang tepat, sampai pada tahap akhir yaitu penyelesaian sesuai dengan prosedur (metode) yang telah dipelajari.

Dari beberapa pendapat parah ahli di atas dapat disimpulkan bahwa, pembelajaran matematika merupakan sekumpulan ilmu yang harus dipahami oleh peserta didik baik dari tingkat sekolah dasar sampai tingkat perguruan tinggi. Pelajaran matematika dipelajari tidak hanya berhitung saja akan tetapi untuk mengetahui hal-hal yang baru.

Berdasarkan observasi awal yang dilakukan oleh peneliti terdahulu pada sekolah MTsN 4 Banda Aceh yang diwakili oleh siswa berinisial NS, terungkap bahwa siswa belum memenuhi indikator pada tahap memahami (Comprehension) dan pada tahap transformasi (Transformation Errors). Hal ini ditunjukkan dari soal yang dijawab siswa bahwasanya siswa NS kurang memahami (Comprehension) soal yang telah dibaca, dan kesulitan dalam mengubah soal cerita ke dalam model matematika (Transformation Errors), sehingga siswa NS kesulitan dalam menyelesaikan soal cerita yang diberikan.

Dari hasil penelitian yang telah dilakukan sebelumnya menunjukkan bahwa siswa masih banyak melakukan kesalahan dalam menyelesaikan soal cerita matematika. Sedangkan menurut Puji Lestari Susilowati dan Novisita Ratu dalam jurnal Mosharafa yang berjudul "Analisis Kesalahan Siswa Berdasarkan Tahapan Newman dan Scaffolding pada materi Aritmatika Sosial", menunjukkan bahwa masih banyak siswa yang melakukan kesalahan dalam menyelesaikan soal cerita matematika pada materi Aritmatika Sosial baik itu kesalahan dalam memahami masalah (Transformation Errors) yang mencapai $13,64 \%$, kesalahan dalam transformasi masalah (transpormatin errors) yang mencapai $14,39 \%$ kesalahan dalam keterampilan proses (proses skills errors) yang mencapai $31,82 \%$, dan kesalahan dalam penulisan jawaban akhir (endcoding errors) yang mencapai 31,82\%. Ini membuktikan bahwa siswa masih banyak melakukan kesalahan dalam menyelesaikan soal cerita matematika.

Berdasarkan hasil wawancara yang telah dilakukan oleh peneliti dengan salah satu guru matematika di SMPK St. Gerardus Mayella Kalembu Weri, menjelaskan bahwa dari hasil ujian tengah semester siswa kelas VII-F dari jumlah 22 siswa hanya 4 siswa yang tuntas dengan persentase 18,18\%. Sedangkan 18 siswa lainnya tidak memperoleh nilai yang tuntas dengan persentase $81,81 \%$. Jika dilihat dari Kriteria Ketuntasan Minimal (KKM) yang di terapkan oleh sekolah yaitu 65, dan lebih banyak siswa yang belum mencapai KKM dari pada yang mencapai KKM.

Oleh sebab itu dapat disimpulkan bahwa penting bagi peneliti untuk menganalisis kesalahankesalahan siswa dalam menyelesaikan soal cerita matematika. Hal ini yang mendorong peneliti untuk meneliti dan membahas kondisi tersebut dalam menyelesaikan soal-soal cerita matematika. Dari pernyataan di atas maka peneliti tertarik untuk melakukan penelitian dengan judul "Analisis Kesalahan Siswa Dalam Menyelesaikan Soal Aritmatika Sosial Kelas VII-F SMPK St. Gerardus Mayella Kalembu Weri Tahun Pelajaran 2020/2021".

\section{Metode Penelitian}

Berdasarkan dengan data, tujuan, dan manfaat dari penelitian ini, maka penelitian ini menggunakan pendekatan penelitian kualitatif. Menurut Rokhimah (2015:32), penelitian kualitatif adalah penelitian yang bermaksud untuk memahami fenomena tentang apa yang dialami oleh subjek penelitian misalnya perilaku, persepsi, motivasi, tindakan, dll., secara holistik, dan dengan cara deskripsi dalam bentuk kata-kata dan bahasa, pada suatu konteks, khusus yang dialamiah dan memanfaatkan berbagai metode ilmiah. 
Subjek dalam penelitian ini adalah siswa kelas VII SMP St. Gerardus Mayella Kalembu Weri. Subjek penelitian ini adalah siswa sebagai individu yang dipilih sebanyak 6 orang siswa. Penetapan subjek penelitian berdasarkan hasil tes. Nilai siswa diurutkan mulai dari peringkat tinggi sampai rendah. Dari urutan nilai tersebut peneliti kemudian menentukan siswa-siswa yang termasuk dalam kategori tinggi, kategori sedang dan kategori rendah. Berdasarkan hasil tes tersebut, diambil masing-masing 2 orang siswa yang diwawancarai untuk mewakili masing-masing kategori siswa kemampuan tinggi (KT), kemampuan sedang (KS) dan kemampuan rendah (KR). Siswa yang diwawancarai adalah siswa yang melakukan kesalahan terbanyak pada masing-masing kategori dan mewakili kesalahan yang dilakukan siswa lain pada kategori yang sama. Pertimbangan lainnya adalah rekomendasi dari guru berdasarkan kemampuan siswa untuk berkomunikasi dan mengungkapkan pendapat/jalan pikirannya baik secara lisan maupun tulisan. Pengumpulan data dalam penelitian ini menggunakan dua cara yaitu dengan tes dan wawancara. Soal tes yang digunakan dalam penelitian ini adalah soal uraian berbentuk soal cerita yang berkaitan dengan aritmatika sosial. Pemilihan soal cerita untuk mengetahui bagaimana jawaban siswa dalam menyelesaikan soal aritmatika sosial. Soal tes dibuat berdasarkan pada kisi-kisi soal yang telah dibuat oleh peneliti. Menurut Juwita (2016:52), analisis data adalah proses mencari dan menyusun secara sistematis data yang diperoleh dari hasil wawancara, catatan lapangan, dan dokumentasi dengan cara mengorganisasikan data ke dalam kategori, menjabarkan ke dalam unit-unit, melakukan sintesa, menyusun ke dalam pola, memilih nama yang penting dan yang akan dipelajari, dan membuat kesimpulan sehingga mudah dipahami oleh diri sendiri maupun orang lain. Data penelitian ini berupa jawaban responden atau soal-soal yang telah diteskan, kemudian diidentifikasikan kesalahannya. Cara pemeriksaan disesuaikan dengan jenis kesalahan yang termuat di dalam setiap butir soal.

\section{Hasil Penelitian dan Pembahasan}

Berikut akan dipaparkan mengenai data lokasi penelitian dan berbagai hal terkait dengan kegiatan penelitian ini. Mulai dari hasil tes, hasil wawancara dan hasil analisis yang masuk dalam kajian pembahasan temuan data. Penelitian ini mengenai analisis kesalahan siswa dalam menyelesaikan soal aritmatika sosial menggunakan tes yang meliputi materi aritmatika sosial. Adapun materi tersebut telah diajarkan pada semester genap pada kelas VII-F. Pada umumnya, data dan hasil temuan penelitian yang dilakukan bahwa hasil penyelesaian soal aritmatika sosial siswa masih saja melakukan kesalahan berdasarkan prosedur Newman. Berdasarkan hasil tes, tidak sepenuhnya bahwa siswa melakukan kesalahan dari 5 prosedur. Hal tersebut diperkuat dari hasil wawancara yang dilakukan setelah pemberian tes. Adapun paparan data yang mewakili temuan data yang akan dibahas secara jelas sebagai berikut.

Adapun nilai persentase siswa dari tiga kategori pada diagram berikut:

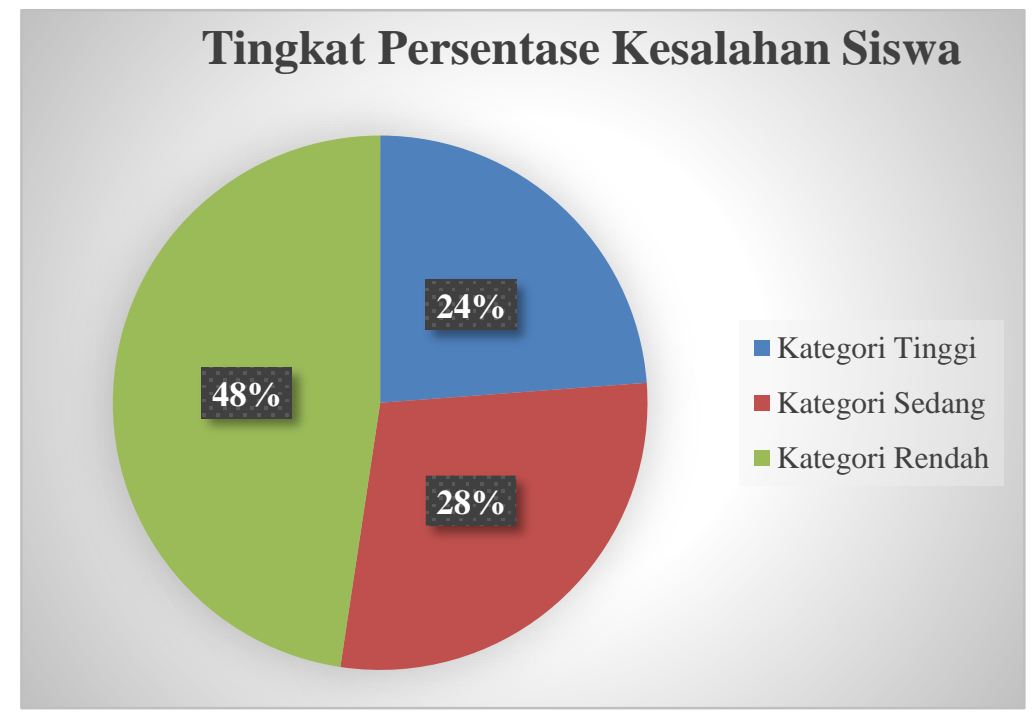

Gambar 4.1 Tingkat persentase kesalahan siswa 
Kette, Making, Ate, Jurnal Penelitian Pendidikan Matematika Sumba, 2021 (3) 1: 34-40

DOI: https://doi.org/10.53395/jppms.v3i1

Berdasarkan diagram lingkaran di atas maka hasil tingkat persentase kesalahan siswa dalam tiga kategori, yaitu:

a. Kategori rendah persentasenya $48 \%$ dengan jumlah siswa yang melakukan kesalahan 10 orang. Seperti yang tertera pada tabel 4.1 .

b. Kategori sedang persentasenya $28 \%$ dengan jumlah siswa yang melakukan kesalahan 6 orang. Seperti yang tertera pada tabel 4.1 .

c. Kategori tinggi persentasenya $24 \%$ dengan jumlah siswa yang melakukan kesalahan 5 orang. Seperti yang tertera pada tabel 4.1

Berikut ini nilai persentase untuk setiap indikator jenis kesalahan berdasarkan prosedur Newman siswa kelas VII-F SMPK St. Gerardus Mayella Kalembu Weri untuk keseluruhan siswa berikut:

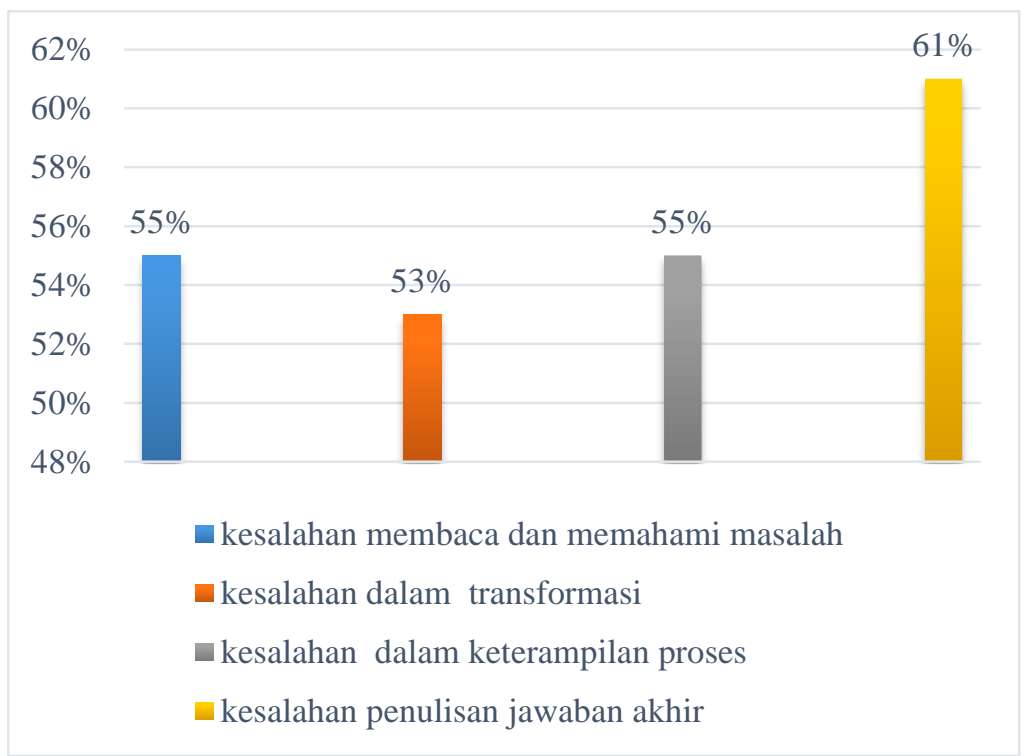

\section{Gambar 4.2 Persentase Kesalahan Siswa untuk Keseluruhan}

Berdasarkan diagram persentase kesalahan siswa untuk keseluruhan di atas maka, untuk kesalahan membaca dan memahami masalah 55\%, kesalahan dalam transformasi 53\%, kesalahan dalam keterampilan proses 55\%, dan kesalahan dalam penulisan jawaban akhir $61 \%$. Adapun siswa-siswi yang dipilih secara acak untuk menganalisis berdasarkan prosedur Newman adalah siswa kelas Siswa kelas VIIF SMPK St. Gerardus Mayella Kalembu Weri.

Data Hasil Tes Siswa dalam Menyelesaikan Soal Aritmatika Sosial sebagai berikut:

\section{Data Hasil Jawaban ML Pada Soal Nomor 1}

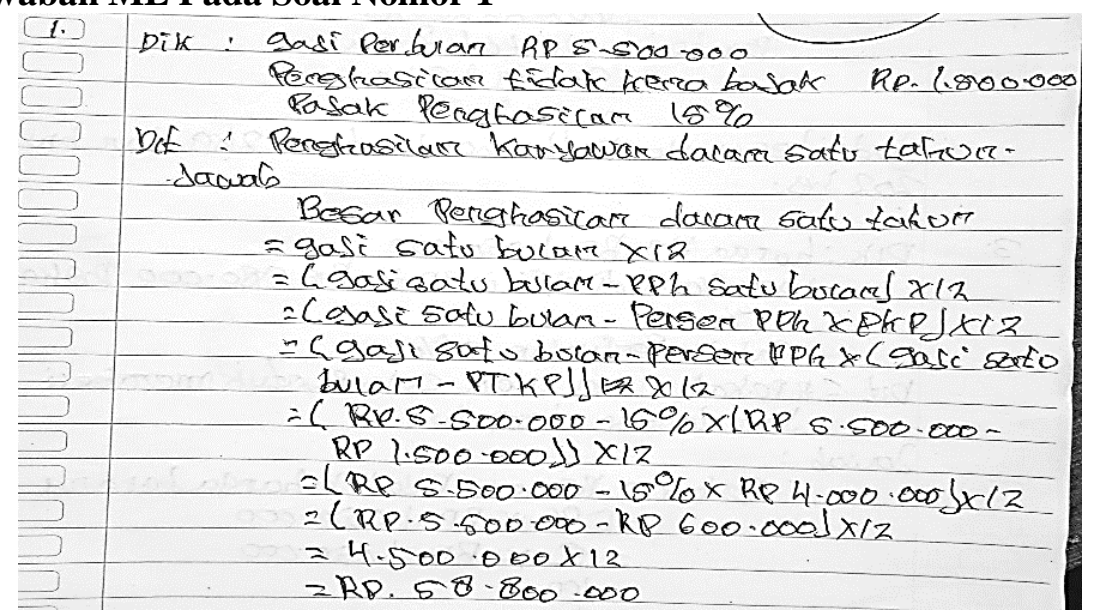

Gambar 4.3 Jawaban siswa untuk soal 1 
Kette, Making, Ate, Jurnal Penelitian Pendidikan Matematika Sumba, 2021 (3) 1: 34-40

DOI: https://doi.org/10.53395/ippms.v3i1
Diketahui : Gaji per bulan Rp 5.500 .000
Penghasilan tidak kena pajak Rp 1.500.000
Pajak penghasilan $15 \%$
Ditanya : : penghasilan karyawan dalam satu tahun.

Jawab:

Besar penghasilan dalam satu tahun

= gaji satu bulan $\times 12$

$=$ (gaji satu bulan $-P P h$ satu bulan) $x 12$

$=($ gaji satu bulan - persen PPh $\times$ PKP) $\times 12$

$=($ gaji satu bulan - persen PPh $x$ (gaji satu bulan - PTKP) $\times 12$

$=(R p 5.500 .000-15 \% \times(R p 5.500 .000-R p 1.500 .000)) \times 12$

$=(\operatorname{Rp} 5.500 .000-15 \% \times R p 4.000 .000) \times 12$

$=(\operatorname{Rp} 5.500 .000-R p 600.000) \times 12$

$=R p 4.500 .000 \times 12$

$=\operatorname{Rp} 58.800 .000$

Adapun hasil wawancara peneliti kepada ENN untuk soal 1

$P \quad$ : Coba perhatikan soal nomor 1, tolong bacakan soal tersebut dengan jelas.

ENN : (Mulai membaca)

$P \quad$ : Informasi apa yang kamu ketahui dari soal tersebut?

ENN : Gaji yang diperoleh karyawan per bulan sebesar Rp 5.500.000, penghasilan tidak

kena pajak Rp 1.500 .000 dan pajak penghasilan $15 \%$ Bu.

$P \quad$ : Permasalahan apa yang terdapat pada soal No 1?

ENN : Penghasilan karyawan dalam 1 tahun $\mathrm{Bu}$.

$P \quad$ :Operasi hitung apa yang kamu gunakan?

ENN : Gaji dalam satu bulan saya kalikan dengan 12 bulan, (setelah itu gaji dalam satu bulan saya kurangi dengan PPh) saya kalikan Lagi dengan 12 bulan. Lalu gaji dalam 1 bulan saya kurangi dengan persen PPh saya kalikan lagi dengan PKP dan di kalikan 12 bulan, dan gaji satu bulan saya kurangi dengan persen PPh lalu dikali dengan gaji satu bulan dan di kurangi dengan PTKP dan saya kalikan dengan 12 bulan Bu.

ENN : Apakah kamu yakin rumus yang kamu gunakan benar?

$P \quad$ : ya saya yakin Bu.

ENN : Mengapa kamu tidak menuliskan jawaban akhirmu?

$P \quad$ : Maaf saya lupa ibu (sambil tersenyum)

ENN : Ok baik

Berdasarkan hasil analisis jawaban dan hasil wawancara yang telah dilakukan oleh peneliti pada ML, bahwa ML melakukan 1 kesalahan yaitu tidak menuliskan jawaban akhir.

\section{Data Hasil Jawaban ML Pada Soal Nomor 2}

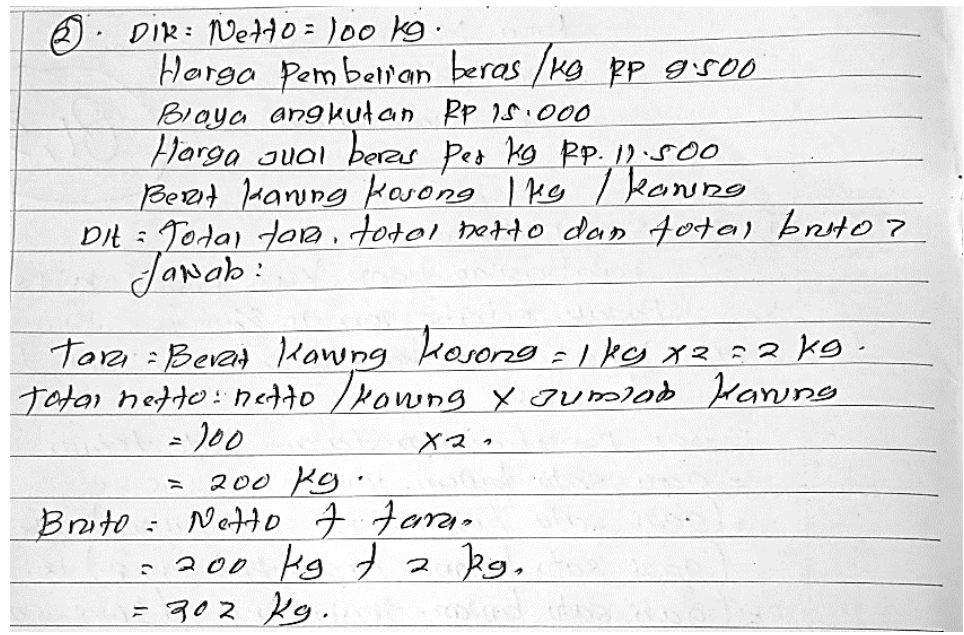

Gambar 4.4 Jawaban siswa untuk soal 2 


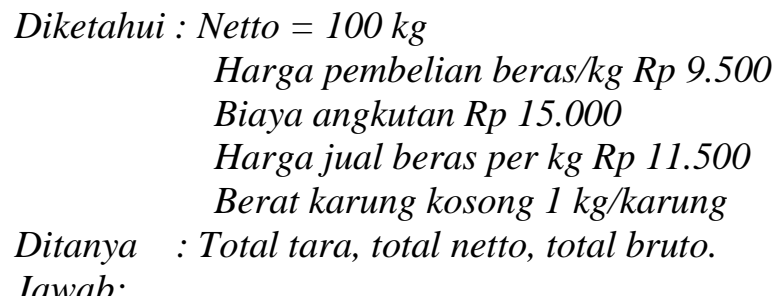

Tara $=$ berat karung kosong $=1 \mathrm{~kg} \times 2=2 \mathrm{~kg}$

Total netto $=$ netto/karung $x$ jumlah karung

$$
=100 \times 2
$$$$
=200 \mathrm{~kg}
$$

Bruto $=$ netto + tara

$=200 \mathrm{~kg}+2 \mathrm{~kg}$

$=202 \mathrm{~kg}$

Adapun hasil wawancara peneliti kepada ML untuk soal Nomor 2

$P \quad$ : Coba perhatikan soal nomor 2, tolong bacakan soal tersebut dengan jelas.

ML : (Mulai membaca)

$P \quad$ : Informasi apa yang kamu ketahui dari soal tersebut?

ML : Netto $100 \mathrm{~kg}$, harga pembelian beras $/ \mathrm{kg} R p$ 9.500,biaya angkutan $\mathrm{Rp} \mathrm{15.000,} \mathrm{harga} \mathrm{jual}$ beras per $\mathrm{kg} R \mathrm{Rp} 11.500$, berat karung kosong $1 \mathrm{~kg} /$ karung $\mathrm{Bu}$.

$P \quad$ : Permasalahan apa yang terdapat pada soal No 1?

ML $\quad$ : Menentukan total tara, total netto dan total bruto Bu.

$P \quad$ : benar, selanjutnya apa yang harus kamu gunakan?

ML : Membuat model matematika Bu.

$P \quad$ : Benar, selanjutnya bisakah kamu menjelaskan langkah-langkah penyelesaian yang digunakan untuk menyelesaikan soal tersebut?

ML : Bisa Bu.

$P \quad$ : Jika bisa, coba jelaskan langkah-langkah penyelesaian dari soal tersebut!

ML : Caranya yaitu tara = berat karung kosong $=1 \mathrm{~kg}$ di kalikan dengan $2=2 \mathrm{~kg}$, setelah itu, total netto $=$ netto/karung di kali jumlah barang, yaitu 100 di kali dengan $2=200 \mathrm{~kg}$ dan bruto $=$ netto di tambah tara selanjutnya $200 \mathrm{~kg}$ di tambah $2 \mathrm{~kg}=202 \mathrm{~kg} \mathrm{Bu}$.

$P \quad$ : Benar, kamu sudah mendapatkan hasil akhir, mengapa kamu tidak menuliskannya?

ML : Buru-buru Bu, mungkin karena waktu yang tinggal sedikit sedangkan soal yang lain masih ada yang belum saya kerjakan $\mathrm{Bu}$.

Berdasarkan hasil analisis jawaban dan hasil wawancara yang telah dilakukan oleh peneliti pada ML, bahwa ML melakukan 1 kesalahan yaitu tidak menuliskan jawaban akhir. Akan tetapi pada saat dilakukan wawancara ML dapat menyebutkan dengan benar informasi apa saja yang terdapat dalam soal dan ML juga dapat menentukan rumus dengan benar dan dapat menjelaskan dengan baik langkah-langkah penyelesaian dari soal tersebut lalu kurang teliti dalam melakukan perhitungan pada soal dan tidak menuliskan kesimpulan akhir dari soal yang telah dia kerjakan.

\section{Kesimpulan dan Saran}

\section{Kesimpulan}

Berdasarkan paparan hasil penelitian dan pembahasan tentang kesalahan siswa dalam menyelesaikan soal aritmatika sosial berdasarkan prosedur Newman sebagai berikut: Jenis kesalahan siswa dalam menyelesaikan soal aritmatika sosial berdasarkan hasil dan analisis data maka dapat disimpulkan yaitu: Kesalahan dalam memahami masalah, yaitu kurang memahami masalah dalam soal sehingga menyebabkan siswa tidak dapat menentukan apa yang diketahui dan yang ditanyakan pada soal. Kesalahan pada tahapan transformasi, yaitu siswa belum mampu menerjemahkan soal ke dalam bentuk model matematika dengan benar, siswa belum mampu menggunakan rumus dengan benar dalam menyelesaikan soal. Kesalahan pada tahapan keterampilan proses, yaitu siswa belum mampu 
melakukan operasi hitung dengan prosedur yang benar dalam mengerjakan soal. Sehingga melakukan kesalahan langkah atau prosedur yang kurang tepat. Kesalahan pada tahapan penulisan jawaban akhir, yaitu siswa tidak membuat kesimpulan jawaban, tidak menemukan hasil akhir jawaban, kekeliruan dalam menuliskan hasil akhir jawaban dikarenakan tidak memeriksa ulang lembar jawaban.

\section{Saran}

Berdasarkan hasil penelitian, maka penulis ingin mengajukan beberapa saran yaitu: Hendaknya memberikan penekanan soal mengenai permasalahan-permasalahan di kehidupan sehari-hari, konsepkonsep dasar dan metode operasinya dalam upaya meningkatkan penguasaan siswa terhadap soal aritmatika sosial, sehingga lebih terbiasa menyelesaikan soal dan dapat meningkatkan kemampuan siswa dalam menyelesaikan masalah matematika. Hendaknya guru lebih kreatif dengan menggunakan metode-metode yang efektif dan menarik dalam menyampaikan materi kepada siswa. Hendaknya siswa juga lebih serius dalam mengikuti pembelajaran demi suksesnya proses belajar mengajar. Peneliti menyadari bahwa masih banyak kekurangan dalam skripsi ini, untuk itu diharapkan untuk peneliti selanjutnya agar dapat melakukan penelitian lebih lanjut untuk dapat mengatasi kesalahankesalahan yang dilakukan siswa dalam menyelesaikan soal aritmatika sosial berdasarkan prosedur Newman.

\section{Daftar Pustaka}

Hanifah, E. H. 2009. Indentifikasi Kesalahan Siswa SMP dalam Menyelesaikan Soal Cerita Matematika Materi System Persamaan Linear Dua Variabel Berdasarkan Analisis Newman (Studi Kasus SMP Bina Bangsa). Surabaya:IAIN

Juwita, Restu. 2016. Analisis Kesalahan dalam Menyelesaikan Soal SPLDV Siswa Kelas VIII SMP IT Wahdah Islamiyah.Skripsi. Fakultas Tarbiyah dan Keguruan UIN Alauddin Makasar.

Malik, Abdul. 2017.Analisis Kesalahan Menyelesaikan Soal Cerita Sistem Persamaan Linear Dua Variabel (SPLDV) Pada Siswa Kelas VIII SMP Negeri 1 Orong Telu. Program Pascasarjana Universitas Terbuka. Jakarta.

Rokhimah, Siti. 2015. Analisis Kesalahan Siswa dalam Menyelesaikan Soal Cerita Matematika Materi Aritmatika Sosial Kelas VII Berdasarkan Prosedur Newman. Skripsi. Fakultas Matematika dan Ilmu Pengetahuan Alam Universitas Negeri Semarang.

Rudtin, N. A. 2013. Penerapan Langkah Polya dalam Model Problem Based Instruction untuk Meningkatan Kemampuan Siswa Menyelesaikan Soal cerita Persegi Panjang. Jurnal. Elektronik Pendidikan Matematika Tadulako.

Syahruddin. 2018. Analisis Kesalahan dalam Menyelesaikan Soal Cerita Operasi Hitung Bilangan Bulat pada Siswa KelasVII SMP Negeri 21 Makasar. Skripsi. Fakultas Matematika dan Ilmu Pengetahuan Alam Universitas Negeri Makasar.

Widdiharto, R. 2004. Model-model Pembelajaran SMP. Yogyakara: Depdikbud. 